\title{
Impact of Global Economic Meltdown on Property Development in Bauchi, Nigeria
}

\author{
Abubakar Mammadi ${ }^{1}$, Habu Mallam Baba ${ }^{1}$, Sadiq Tukur ${ }^{1}$, Abdulazeez Adam Muhammad ${ }^{1}$ \\ ${ }^{1}$ Abubakar Tafawa Balewa University \\ Tafawa Balewa Way, P. M. B. 0248, Bauchi, 740272, Nigeria
}

DOI: $10.22178 /$ pos.53-3

JEL Classification: 018

Received 30.11.2019

Accepted 28.12.2019

Published online 31.12.2019

Corresponding Author:

Abubakar Mammadi

abubakarmammadi@gmail.com

(C) 2019 The Authors. This article

is licensed under a Creative Commons

Attribution 4.0 License @) (1)

\begin{abstract}
The global economic meltdown is a situation in which the economy of a country experiences a sudden downturn brought on by a financial crisis. This global recession was caused by so many factors, thus, inflation rate, exchange rate, interest rate, unemployment rate, etc. This paper examined the impact of the global economic meltdown on property development in Bauchi, Nigeria. Data for the study are mainly primary in the form of questionnaires administered. The study had property development as an endogenous variable while a high-interest rate and unemployment rate as exogenous variables to measure the constructs. Multiple Regression were used to analyze the data. Among the study, findings are that high relationship exists between the two predictor variables (High-Interest Rate \& Unemployment Rate) and dependent variable (property Development) where ' $R$ ' of 0.724 means the correlation is about $72 \%$; with $\mathrm{R}^{2}$ of 0.052 indicate that $5.2 \%$ correlation, the analysis also depict in coefficient table that high-interest rate has more influence on dependent variable (PD) than unemployment rate. The analysis signified that the impact of the global economic meltdown has a positive effect on the dependent variable. Based on the findings, the study recommended governments and financial institutions intervention to curb the impediment of property development in Bauchi, Nigeria.
\end{abstract}

Keywords: Economic Meltdown; Property Development; Housing Market; Interest Rate.

\section{INTRODUCTION}

The economic meltdown or in other words recession can be conceived as a period of general economic decline and is typically accompanied by a drop in the stock market, an increase in unemployment, and a decline in the housing market, etc. The global economic meltdown is an issue that concerns everyone as long as planet earth is concerned. Author [6] further puts it thus "The global financial crisis, of which the aftermath is still being felt, has been tagged the most severe financial crisis experienced by the world since the great depression of the last century. The crisis had an unprecedented impact on property development, credit, and capital, the housing market, interest rate, unemployment, taking offshoot from the financial markets in the US, with the contagion and impact spreading unevenly across the globe", and Nigeria as a nation is not left out. The current crisis began with cheap housing loans offered by banks. Banks provided loans but instead of holding the loan in their books, they packaged them into collateralized debt obligations (CDOs) and sold them to other agencies. These agencies passed them on to others and spread them globally as assets [17].

Author [17] further opined that Interest rates were brought down and housing loans increased with construction activities leading to land prices going up. The real estate was booming, creating employment and incomes. But as the rate of interest on housing loans came down, banks began to compete to secure more business. Because of low-interest rates, it was possible to borrow more from the same monthly payment to pay the old loan and still have some left as a surplus for a vacation or to buy other assets. Others went for a second house as an investment. This system called refinancing rose from $\$ 15$ billion in 1995 to nearly $\$ 250$ billion a decade later. The problem started when housing loans came to be at rates below the prime rates of banks (sub-prime 
lending). Banks believed that land prices will continue to rise and did not bother to scrutinize the economic credentials of borrowers and their ability to pay back. Lack of proper information to borrowers and gradual rising of interest created difficulties for some borrowers to close the mortgages. Author [6] asserted that, in Nigeria, the effect of the crisis was not felt until the mid-2008 up to the present time. World economic interdependence gave room to the financial crisis in all economies of the world including Nigeria. The sell-off by foreign investors affected the stock market and the economic downturn in the US (a major export destination for the Nigeria Crude oil) affected the demand and resulting in the fall of the oil price. Consequence upon that, Investors in Nigeria are losing their investments in stock and property development sectors lack developers as there is little money in circulation to finance any housing development project, and this phenomenon was envisaged in Bauchi Property Investment and Development Company in which the Organization was shut down as a result.

\section{Statement of research problem}

The global economic meltdown has engendered a direct impact on property development tempo and which has vagary for unemployment and high-interest rate as many industries and organizations are folding. As Nigeria is gradually coming to term with the global economic crisis, a sharp drop in property value are becoming evident in the country [10].

The aftermath of the recession has devastated the activities of landed property dealings in all ramifications in Bauchi Metropolis. These problems are envisaged in property development, unemployment rate, high-interest rate, etc. which stagnate progress and hardship in the State in general.

This global economic meltdown which was first experienced in 1993, 2009 and even up to date in which the aftermath is still been felt cannot be overemphasis. However, this study among others will look at the effect of the global economic meltdown on property development in Bauchi, Nigeria.

\section{Literature review}

Researcher [2] defines economic meltdown as economic "go slow" that stagnate the growth of the economy. Author [14] defines economic meltdown as a dangerous accident affecting the trade, industry, and development of wealth and the management of country money. The global economic meltdown which started in 2007 led to the collapse of the commercial real estate market in the US and came on the heels of the worst financial crisis observed since the Great Depression according to [13]. Indeed, developers, investors, lenders, policy-makers, and regulators seemed unprepared for the downturn, claiming it was unprecedented and thus unpredictable.

The global financial crisis presents significant challenges for African countries with Nigeria not exempted. Apart from exposing the functioning of the global economy which led to calls for global financial architecture, it has also caused a collapse in the value of real estate assets and turns seriously damaged their attractiveness to both prospective and existing investors. This was self-evident in the decline of demand for rate for some properties especially in the upscale markets in Abuja and Lagos [11].

The financial crisis invariably led to the collapse of America's largest Mortgage institutions; Federal Home Loan Mortgage Corporations (Freddie Mac) and Federal National Mortgage Association (Fannie Mae) as well as other globally important investment banks such as Bear Stearns, Lehman Brothers and Merrill Lynch [9]. According to [3], an estimate put total world wealth at $\$ 44$ trillion, of which approximately half is real estate. A study by [12], confirmed that the Nigerian property market was hit strongly by the global recession with business and consumer confidence plummeting, development companies cutting back productions and/ or employment in response falls in demand, and difficulties in accessing credit due high-interest rate, housing among others. According to the study, the downturn is affecting the residential property sector on many levels; in effect, apart from the obvious impact of the fall in property prices, the downturn has battered other closely related sectors like the construction industry. This position was further supported by [1] when he confirms a drastic drop in the demand for residential properties either for occupation or investment purposes. Author [3] also asserted that landlords were feeling the pressure from tenants who were negotiating to reduce rents and push for rent-free periods to improve cash-flow and these factors were having severe implications on institutional investors who realized that the value of their invest- 
ments was falling. Furthermore, the inefficiency of mortgage institutions in Nigeria had invariably instigated financial institutions (commercial banks) to take over the responsibility of the provision of loans for property development [8]. According to [10], when the financial crisis resulted in a credit crunch among most financial institutions, it resulted in a shortfall of finance available for real estate development.

Moreover, as the collapse of the global housing bubble which peaked in 2006 triggered the values of securities tied to real estate plummet, this invariably caused a major source of distress for institutional investors. The decline in credit availability and investor confidence also harmed the Nigerian capital market, where investors suffered large losses to the tune of about N556 Billion during late 2008 and early 2009. Economies worldwide slowed during this period as credit tightened and international trade declined [10].

The crisis has produced or exacerbated serious, wide-ranging yet differentiated impacts across the globe. Negative impacts are reported mainly from developing countries and within them, some have serious problems though they did not cause the problem [8].

According to [16] the following are noted by the UN:

- Increasing unemployment (50 million jobs lost according to the International Labor Organization), poverty and hunger;

- Deceleration of growth, economic contraction;

- Negative effects on trade balances and balance of payments;

- Dwindling levels of foreign direct investment;

- Large and volatile movements in exchange rates;

- Growing budget deficits, falling tax revenues and reduction of fiscal space;

- Contract action of world trade;

- Increasing volatility and falling prices for primary commodities;

- Declining remittances to developing countries;

- Sharply reduced revenues from tourism;

- Massive reversal of private capital flows;

- Reduced access to credit and trade financing;

- Reduced public confidence in financing institutions;

- Reduced ability to maintain social safety nets and provide other social services, such as health and education;

- Increased infant and maternal mortality;

- The collapse of housing markets;
- The debt levels of man developing countries are over $150 \%$ of GDP.

The crisis threatens to have calamitous human and developmental consequences. Millions of people all over the world are losing jobs, their income their savings and their homes. The World Bank estimates that more than 50 million people have already been driven into extreme poverty, particularly women and children. The Food and Agriculture Organization of the United Nations project that the crisis will contribute to a rising number of hungry and undernourished people worldwide to a historic high of over one billion. Developing countries will suffer more than developed countries. These countries that have no role in causing the crisis have suffered the most "collateral damage" [7].

Almost all of the negative impacts mentioned above apply to Africa as well. Africa was, however not seriously affected in the beginning by the financial crisis since there was a low level of financial integration with the world markets, in the first place. It is now affected, however, due to the shocks and disturbance coming from the global economy through international markets which are vehicles of transmission to national economies. According to the International Trade Confederation Africa Region (ITUC), in Africa the effects of the crisis have spread through four main markets: The goods and services markets, capital markets, exchange markets and labor markets [7]. This study investigated the impact of economic meltdown on property development in Bauchi Metropolis in consideration of the housing market, interest rate and unemployment rate in the study area (Figure 1).

\section{EXOGENOUS}

ENDOGENOUS

\begin{tabular}{|l|l|}
\hline High interest rate & $\begin{array}{c}\text { Property } \\
\text { development }\end{array}$ \\
\hline Unemployment rate & $\longrightarrow$ \\
\hline
\end{tabular}

Figure 1 - A conceptual relationship between Global economic meltdown and property development

\section{METHODOLOGY}

The study adopts both primary and secondary data in determining the relationship between the independent variables and the dependent variable. The primary data in a form of a questionnaire was administered on property developers, estate agents, mortgage/commercial banks, civil 
servants and community members within the metropolis to generate information on the interest rate, unemployment rate and property development constrain. On the other hand, the secondary source was mainly obtained from journals, articles and the Federal Office of Statistics (FOS). The data consist of such specific performance variables as the unemployment rate and decline in property development issues.

The technique used for collecting data was a closed-ended questionnaire designed in a 5Likert scale ranging from strongly disagrees to strongly agree randomly distributed. There are four sections of the questionnaire design; section ' $A$ ' has five questions and covers demographic information. Section 'B' covered independent variable ' high-interest rate' and hasten relevant measurement items. Section ' $C$ ' is another exogenous variable 'unemployment rate' with nine questions. Section ' $D$ ' is an endogenous variable 'property development' with also ten measurement items making a total of 29 measurement items. A total of 210 questionnaires were distributed using a systematic sampling method which enables the spread of the members selected for measurement more evenly across the entire population without bias. And 196 filled questionnaires were retrieved. A population size of 400 can be represented by a sample of 196 respondents, and Multiple Regression Analysis (MRA) in the IBM version of SPSS was adopted to analyze the impact and relationship between the variables (Table 1).

Table 1 - Distribution of Respondents

\begin{tabular}{|l|r|r|r|}
\hline \multicolumn{1}{|c|}{ Parameters } & Frequency & Percent & $\begin{array}{c}\text { Cumulative, } \\
\%\end{array}$ \\
\hline \multicolumn{4}{|c|}{ Gender } \\
\hline Male & 124 & 63.3 & 63.3 \\
\hline Female & 72 & 36.7 & 100.0 \\
\hline \multicolumn{4}{|c|}{ Age } \\
\hline $18-30$ & 34 & 17.3 & 17.3 \\
\hline $31-40$ & 38 & 19.4 & 36.7 \\
\hline $41-50$ & 69 & 35.2 & 71.9 \\
\hline $51-60$ & 41 & 20.9 & 92.9 \\
\hline 61 and above & 14 & 7.1 & 100.0 \\
\hline \multicolumn{4}{|c|}{ Occupation } \\
\hline Civil servant & 77 & 39.3 & 39.3 \\
\hline Self employed & 69 & 35.2 & 74.5 \\
\hline Unemployed & 50 & 25.5 & 100.0 \\
\hline
\end{tabular}

\begin{tabular}{|c|c|c|c|}
\hline Parameters & Frequency & Percent & $\begin{array}{c}\text { Cumulative, } \\
\%\end{array}$ \\
\hline \multicolumn{4}{|c|}{ Income } \\
\hline $1000-2000$ & 34 & 17.3 & 17.3 \\
\hline $21000-40000$ & 33 & 1.8 & 34.2 \\
\hline $41000-60000$ & 54 & 27.6 & 61.7 \\
\hline $61000-100000$ & 39 & 19.9 & 81.6 \\
\hline $101000-150000$ & 19 & 9.7 & 91.3 \\
\hline $151000-200000$ & 10 & 5.1 & 96.4 \\
\hline $\begin{array}{l}201000 \text { and } \\
\text { above }\end{array}$ & 7 & 3.6 & 100.0 \\
\hline \multicolumn{4}{|c|}{ Education } \\
\hline $\begin{array}{l}\text { Non formal } \\
\text { education }\end{array}$ & 40 & 20.4 & 20.4 \\
\hline Secondary school & 60 & 30.6 & 51.0 \\
\hline ND / NCE & 56 & 28.6 & 79.6 \\
\hline BSc / HND & 34 & 17.3 & 96.9 \\
\hline $\mathrm{PhD} / \mathrm{MSc}$ & 6 & 3.1 & 100.0 \\
\hline
\end{tabular}

This study aimed at measuring the impact of global economic meltdown on property development in Bauchi Metropolis, Nigeria by relating high-interest rate (HIR) to unemployment rate (UER) as a yardstick: $\mathrm{H} 1$ - the high-interest rate has a direct impact on property development; $\mathrm{H} 2$ - unemployment rate has direct impact on property development.

\section{RESULTS AND DISCUSSIONS}

Normality Test. This test was imperative to ensure the distributions of the variables whether normal or otherwise. In regards to this study, the table and histogram below revealed that the distributions of variables and representations of curves (skewness, kurtosis) were normal (Table 2, Figure 2).

Reliability analysis. This piece of work has two independent variables and one dependent variable. The investigations involved 29 measurement items for the three constructs and were subjected to reliability analysis to meet the standard level of consistency between the items mentioned, however, the inconsistent items were removed for re-analysis and this reduced the measurement items to 20 (Tables 3, 4). The internal consistency of the measurement items was investigated by Cronbach's Alpha $[4,5,15]$ alpha value from 0.7 to 0.95 depicts good internal consistency of items. 
Table 2 - Statistic of Normality Distributions

\begin{tabular}{|c|c|c|c|c|c|c|}
\hline & Inflation & Supply/Demand & $\begin{array}{c}\text { Loan } \\
\text { Amount }\end{array}$ & Government & $\begin{array}{c}\text { Purchasing } \\
\text { Power }\end{array}$ & $\begin{array}{c}\text { Opportunity } \\
\text { Cost }\end{array}$ \\
\hline Valid & 196 & 196 & 196 & 196 & 196 & 196 \\
\hline Mean & 3.60 & 3.51 & 3.63 & 3.64 & 3.48 & 3.43 \\
\hline Median & 3.75 & 4.00 & 4.00 & 4.00 & 3.40 & 4.00 \\
\hline Std. Deviation & .620 & 1.121 & 1.231 & 1.242 & .605 & 1.336 \\
\hline Variance & .384 & 1.256 & 1.516 & 1.544 & .366 & 1.785 \\
\hline Skewness & -.177 & -.556 & -.651 & -.688 & -.223 & -.417 \\
\hline $\begin{array}{l}\text { Std. Error of } \\
\text { Skewness }\end{array}$ & .174 & .174 & .174 & .174 & .174 & .174 \\
\hline Kurtosis & -.188 & -.379 & -.536 & -.506 & -.563 & -1.046 \\
\hline $\begin{array}{l}\text { Std. Error of } \\
\text { Kurtosis }\end{array}$ & .346 & .346 & .346 & .346 & .346 & .346 \\
\hline
\end{tabular}

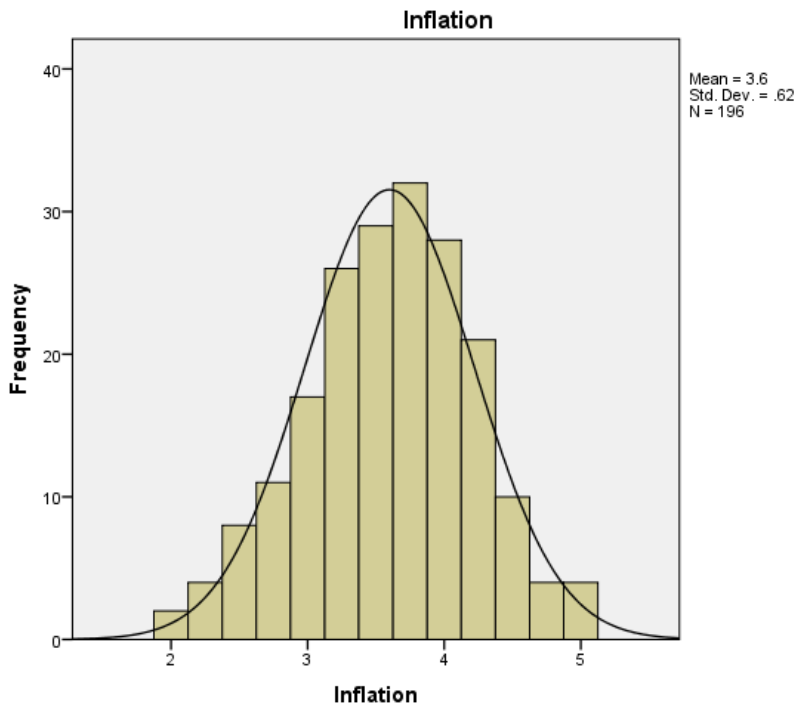

Figure 2 - Histogram showing normal distributions to skewness and kurtosis

Table 3 - Reliability Analysis

\begin{tabular}{|l|l|c|c|c|}
\hline No & $\begin{array}{c}\text { Independents } \\
\text { and Dependent } \\
\text { Constructs }\end{array}$ & $\begin{array}{c}\text { Cronbach's } \\
\text { Alpha }\end{array}$ & $\begin{array}{c}\text { Cronbach's } \\
\text { Alpha Based } \\
\text { on } \\
\text { Standardized } \\
\text { Items }\end{array}$ & $\begin{array}{c}\text { No of } \\
\text { Items }\end{array}$ \\
\hline 1 & $\begin{array}{l}\text { High Interest } \\
\text { Rate }\end{array}$ & 0.584 & 0.692 & 10 \\
\hline 2 & $\begin{array}{l}\text { Unemployment } \\
\text { Rate }\end{array}$ & 0.529 & 0.651 & 9 \\
\hline 3 & $\begin{array}{l}\text { Property } \\
\text { Development }\end{array}$ & 0.613 & 0.714 & 10 \\
\hline & Total & & 29 \\
\hline
\end{tabular}

Table 4 - Reliability Analysis Second Run

\begin{tabular}{|l|l|c|c|c|}
\hline No & $\begin{array}{c}\text { Independents } \\
\text { and Dependent } \\
\text { Constructs }\end{array}$ & $\begin{array}{c}\text { Cronbach's } \\
\text { Alpha }\end{array}$ & $\begin{array}{c}\text { Cronbach's } \\
\text { Alpha Based } \\
\text { on } \\
\text { Standardized } \\
\text { Items }\end{array}$ & $\begin{array}{c}\text { No of } \\
\text { Items }\end{array}$ \\
\hline 1 & $\begin{array}{l}\text { High Interest } \\
\text { Rate }\end{array}$ & 0.826 & 0.865 & 8 \\
\hline 2 & $\begin{array}{l}\text { Unemployment } \\
\text { Rate }\end{array}$ & 0.806 & 0.832 & 6 \\
\hline 3 & $\begin{array}{l}\text { Property } \\
\text { Development } \\
\text { Total }\end{array}$ & 0.931 & 0.957 & 6 \\
\hline
\end{tabular}

Correlation analysis. This test for the relationship between the three constructs (high-interest rate, unemployment rate, property development). It entailed that, if the values of independent variables (IVs) are high up to 0.85 means that one of the IV is redundant, therefore, a value from 0.255 below deemed accepted. In other word, the IVs relationships are expected to be low but between IVs and dependent variables (DV) are expected to be high up to 1.96 . The tables 5,6 below present the scenario of the analysis.

Table 5 - Correlations between the IVS

\begin{tabular}{|c|l|c|c|}
\hline \multicolumn{2}{|l|}{} & HI & UE \\
\hline \multirow{4}{*}{ HI } & Pearson Correlation & 1 & $.158^{*}$ \\
\cline { 2 - 4 } & Sig. (2-tailed) & & .027 \\
\cline { 2 - 4 } & N & 196 & 196 \\
\hline \multirow{3}{*}{ UE } & Pearson Correlation & $.158^{*}$ & 1 \\
\cline { 2 - 4 } & Sig. (2-tailed) & .027 & \\
\cline { 2 - 4 } & N & 196 & 196 \\
\hline
\end{tabular}

Notes: *Correlation is significant at the 0.05 level (2tailed) 
Table 6 - Correlations of IVs on DV

\begin{tabular}{|c|l|c|c|c|}
\hline \multicolumn{2}{|l|}{} & HI & UE & PD \\
\hline \multirow{3}{*}{ HI } & Pearson Correlation & 1 & $.158^{*}$ & .025 \\
\cline { 2 - 5 } & Sig. (2-tailed) & & .027 & .724 \\
\cline { 2 - 5 } & $\mathrm{N}$ & 196 & 196 & 196 \\
\hline \multirow{3}{*}{ UE } & Pearson Correlation & $.158^{*}$ & 1 & -.045 \\
\cline { 2 - 5 } & Sig. (2-tailed) & .027 & & .529 \\
\cline { 2 - 5 } & $\mathrm{N}$ & 196 & 196 & 196 \\
\hline \multirow{3}{*}{ PD } & Pearson Correlation & .025 & -.045 & 1 \\
\cline { 2 - 5 } & Sig. (2-tailed) & .724 & .529 & \\
\cline { 2 - 5 } & $\mathrm{N}$ & 196 & 196 & 196 \\
\hline
\end{tabular}

Notes: *Correlation is significant at the 0.72 level (2tailed)
Multiple regression analysis. Good relationship exists between the two predictor variables (HighInterest Rate and Unemployment Rate) and the dependent variable (Property Development) as depicted on table 7 below where ' $R$ ' is the correlation of IVs on DV with the value of 0.724 means the correlation is about $72 \%$, and ' $\mathrm{R}^{2}$ ' is causal effect or influence of IVs on DV with value 0.052 explained that $5.2 \%$ of the variance independent variable is shown by the predictor variables, and the influence is significant.

Table 7 - Model Summary of High Interest Rate, Unemployment Rate and Property Development

\begin{tabular}{|c|c|c|c|c|c|c|c|c|c|}
\hline \multirow[b]{2}{*}{ Model } & \multirow[b]{2}{*}{$\mathrm{R}$} & \multirow{2}{*}{$\begin{array}{c}\mathrm{R} \\
\text { Square }\end{array}$} & \multirow{2}{*}{$\begin{array}{l}\text { Adjusted R } \\
\text { Square }\end{array}$} & \multirow{2}{*}{$\begin{array}{l}\text { Std. Error of the } \\
\text { Estimate }\end{array}$} & \multicolumn{5}{|c|}{ Change Statistics } \\
\hline & & & & & $\begin{array}{l}\text { R Square } \\
\text { Change }\end{array}$ & $\begin{array}{c}\mathrm{F} \\
\text { Change }\end{array}$ & df1 & $\mathrm{df} 2$ & $\begin{array}{c}\text { Sig. F } \\
\text { Change }\end{array}$ \\
\hline 1 & $.724 a$ & .052 & .373 & .47857 & .003 & .303 & 2 & 193 & .000 \\
\hline
\end{tabular}

Notes: Predictors: (Constant), Unemployment, High Interest

The unique effects of the predictors reflect a very low and negative correlation between unemployment and high-interest rate $(-051)$, this is not significant. But the high and positive correlation was present between property develop- ments (.812). This scenario represents that the high-interest rate has more influence on the dependent variable (PD) than the unemployment rate. This analysis is in Table 8 below.

Table 8 - Coefficients Table

\begin{tabular}{|c|c|c|c|c|c|c|c|c|c|c|c|c|}
\hline \multirow{2}{*}{ Model } & \multicolumn{2}{|c|}{$\begin{array}{c}\text { Unstandardized } \\
\text { Coefficients }\end{array}$} & \multirow{2}{*}{$\begin{array}{c}\begin{array}{c}\text { Standardized } \\
\text { Coefficients }\end{array} \\
\text { Beta }\end{array}$} & \multirow[t]{2}{*}{$\mathrm{T}$} & \multirow{2}{*}{ Sig. } & \multicolumn{2}{|c|}{$\begin{array}{c}95.0 \% \\
\text { Confidence } \\
\text { Interval for B }\end{array}$} & \multicolumn{3}{|c|}{ Correlations } & \multicolumn{2}{|c|}{$\begin{array}{l}\text { Collinearity } \\
\text { Statistic }\end{array}$} \\
\hline & B & $\begin{array}{c}\text { Std. } \\
\text { Error }\end{array}$ & & & & $\begin{array}{l}\text { Lower } \\
\text { Bound }\end{array}$ & $\begin{array}{l}\text { Upper } \\
\text { Bound }\end{array}$ & $\begin{array}{l}\text { Zero- } \\
\text { order }\end{array}$ & Partial & Part & Tolerance & VIF \\
\hline (Constant) & 3.455 & .362 & & 9.540 & .000 & 2.741 & 4.170 & & & .033 & & \\
\hline $1 \mathrm{HI}$ & .039 & .085 & -0 & .458 & .647 & -129 & .208 & .025 & .033 & 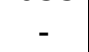 & .97 & 1.025 \\
\hline UE & -051 & .074 & .812 & -694 & .000 & -196 & .094 & -045 & -050 & 050 & .975 & 1.025 \\
\hline
\end{tabular}

Notes: Dependent Variable: Property Development

In consideration of the cumulative effects of exogenous variables on the endogenous variable has that, the cumulative effects of the independent variables (IVs) on the dependent variable (DV) should not be above 0.05 significant level at 2 degrees of freedom (df). The analysis using Analysis of Variance (ANOVA) in Table 9 below, revealed that the significant value 0.048 cumulative effects of IVs on DV is significant as is $>0.05$ level.
Table 9 - ANOVA table

\begin{tabular}{|l|c|c|c|c|c|}
\hline \multicolumn{1}{|c|}{ Model } & $\begin{array}{c}\text { Sum of } \\
\text { Squares }\end{array}$ & Df & $\begin{array}{c}\text { Mean } \\
\text { Square }\end{array}$ & F & Sig. \\
\hline Regression & .139 & 2 & .070 & .303 & $.048 b$ \\
\hline Residual & 44.202 & 193 & .229 & & \\
\hline Total & 44.341 & 195 & & & \\
\hline
\end{tabular}

Notes: a) Dependent Variable: PD; b) Predictors: (Constant), UE, HI 


\section{CONCLUSION}

This work oblique in studies the impact of global economic meltdown on property development in Bauchi, Nigeria by considering three constructs (IVs \& DV) with 29 measurement items, as a major yardstick in determining the results of the study. The internal consistency of the variables mentioned are as follow; High Interest $=0.826$, Unemployment Rate $=0.806$, Property Development $=0.931$ respectively. The accepted standard range from 0.7 to 0.95 , with this regard, the internal consistency of the study deduced accepted as are within the range. The relationship of IVs on DV is 0.724 value which is $72 \%$ and this means relationship exists, and in the same vein, the influence of IVs on DV is 0.052 which ex- pressed as $5.2 \%$ and is significant. The study also revealed that the high-interest rate (HI) has more influence on property development (PD) than on the unemployment rate (UE). The analysis is presented that; global economic meltdown has a positive effect on the dependent variable under study.

In consideration of this result, development financial institutions must mention few; stock and share, development banks, pension funds, mortgage banks, etc. to encourages property developers by way of reducing interest rate and stringent procedures would go a long way in solving the problems of property development in Bauchi and the country at large.

\section{REFERENCES}

1. Abisagbo A. 0. (2010). The effect of the global economic recession on the residential property market in Lagos Metropolis (Master's Dissertation); University of Lagos.

2. Adamu, A. (2009). The Effects of Global Financial Crisis on Nigerian Economy. SSRN Electronic Journal. doi: 10.2139/ssrn.1397232

3. Adamu-Iria, M. (2007). Analysis of the causes of the recent global financial crisis and how it may affect the Nigerian economy. Lagos: Onward press.

4. Gençtürk, E., Gökçek, T., \& Güneş, G. (2010). Reliability and validity study of the technology proficiency self-assessment scale. Procedia - Social and Behavioral Sciences, 2(2), 2863-2867. doi: 10.1016/j.sbspro.2010.03.429

5. Gliem, J. A., \& Gliem, R. R. (2003). Calculating, Interpreting, and Reporting Cronbach's Alpha Reliability Coefficient for Likert-Type Scales. Retrieved from https://scholarworks.iupui.edu/bitstream/handle/1805/344/Gliem\%20\%26\%20Gliem.pdf?se quence $=1 \&$ isAllowed $=\mathrm{y}$

6. KA. (2013, November 28). The Impact of the Global Financial Crisis on the Nigerian Economy. Retrieved from https://www.proshareng.com/news/Nigeria-Economy/The-Impact-of-theGlobal-Financial-Crisis-on-the-Nigerian-Economy/21641

7. Khomo, J., Nziapono, O. (2007). Global Economic Outlook 2007: Is a Crisis Imminent, or are things better than we thought? Retrieved from https://bit.ly/37xJXk3

8. Khoza, F., \& Dyasi, Th. (2017, May). The Financial Sector Regulation Bill, 2015 and the regulation of financial conglomerates. Retrieved from https://financialmarketsjournal.co.za/the-financialsector-regulation-bill-2015-and-the-regulation-of-financial-conglomerates/

9. Krugman, P. (2009, January 27). A dark age of macro-economics. Retrieved from https://krugman.blogs.nytimes.com/2009/01/27/a-dark-age-of-macroeconomics-wonkish/

10. Obi, C. K. (2009). Global financial meltdown and millennium development goals. Retrieved from https://mpra.ub.uni-muenchen.de/75231/

11. Ogunleye. (2009, March 5). How global financial meltdown has affected Nigerian banks. NBF News. Retrieved from http://www.nigerianbestforum.com/blog/how-global-financial-meltdown-hasaffected-nigerian-banks-ndic-boss-ogunleye/ 
12. Oyesiku, O. (2009). Global Economic Recession, the Environment and Sustainable Development in Nigeria. Urban journal, 2, 40-46.

13. Rogoff, J. (2009). The benefit of real estate investment hostess. Retrieved from https://www.unsystem.org/content/global-financial-and-economic-crisis-1

14. Strauss-Kahn, D. (2009, September 18). IMF Survey: Social Risks Ahead If Jobs Crisis Is Not Addressed - IMF. Retrieved from https://www.imf.org/en/News/Articles/2015/09/28/04/53/soint091809a

15. Tavakol, M. \& Dennick, R. (2011). Making Sense of Cronbach's Alpha. International Journal of Medical Education, 2, 53-55. doi: 10.5116/ijme.4dfb.8dfd

16. United Nations. (2009, June). Report of the Conference on the World Financial and Economic Crisis and Its Impact on Development. Retrieved from https://bit.ly/35fnSW4

17. Windapo A.O. (2009) Challenges of the Global Economic Recession and its Challenges for Housing Development and management in Nigeria. In: Proceedings of the National Conference on The Global Financial Meltdown: Challenges and Opportunities for the Construction industry, Nigerian Institute of Building, Makurdi, 8-12 July, 39, 39-45. 